\title{
Contraceptive practices and awareness about emergency contraception among women attending a tertiary care hospital of Delhi, India
}

\author{
Prachi Renjhen $^{1}$, Vikas Kumar ${ }^{2 *}$, Akanksha Rathi ${ }^{2}$, Attuluri Loukya ${ }^{1}$
}

\begin{abstract}
${ }^{1}$ Department of Gynecology, ${ }^{2}$ Department of Community Medicine Dr. Baba Saheb Ambedkar Medical College and Hospital, Delhi, India, India
\end{abstract}

Received: 04 January 2019

Accepted: 05 February 2019

\section{*Correspondence:}

Dr. Vikas Kumar,

E-mail: drvikaspsm@gmail.com

Copyright: (c) the author(s), publisher and licensee Medip Academy. This is an open-access article distributed under the terms of the Creative Commons Attribution Non-Commercial License, which permits unrestricted non-commercial use, distribution, and reproduction in any medium, provided the original work is properly cited.

\begin{abstract}
Background: Emergency contraceptive pills (ECs) are a safe female-controlled method of post-coital contraception; however, the knowledge about them is low among general population.

Methods: This cross-sectional study was done among the adult females, aged 18 years and above, who visited the various out-patient departments (OPD) of a tertiary care hospital in July 2017. A total of 640 adult females, who visited the OPDs of medicine, surgery, orthopedics and gynecology were included in this study. Data were entered and analyzed using SPSS ver 16. Chi-square test was used to test association. A p-value of less than 0.05 was considered as significant association.

Results: Of the 640 participants, mostly were Hindu, aged between 20-29 years, married and had more than one child. Only, $52 \%$ females were aware of the term 'contraception' and $17.7 \%$ about 'emergency contraception'. The only method of ECs they were aware of was i-pill. Commonest source of their knowledge was friends, relatives and spouse. Only 70 women knew that it can be used after unprotected intercourse and 25 knew that it can be used after failure of barrier method. Just $41.2 \%$ women used any kind of contraceptive and 5.3\% women have ever used an EC. Around $28 \%$ women reported not using contraception due to lack of knowledge.

Conclusions: Despite of their availability since many years, awareness about emergency contraception is low. More efforts are required to generate awareness about regular use of effective contraception and emergency contraception if required.
\end{abstract}

Keywords: Awareness, Emergency contraception, Knowledge, New Delhi

\section{INTRODUCTION}

India is the second most populous country of the world and the lower socio-economic strata is grappling with issues like uncontrolled births and unintended pregnancies. Population explosion not just exhausts resources, but unwanted births are disadvantaged in terms of maternal and child health outcomes. ${ }^{1}$ Despite of widespread efforts of the government to improve the contraception use, the contraception prevalence is as low as $64 \% .^{2}$ The knowledge of contraception is widespread but vast majority of married Indians reported significant problems in accessing a choice of contraceptive methods. ${ }^{3}$ Emergency contraceptive pills (ECs), made legal in India in 2003 and available over the counter from pharmacists since 2005, are a safe female-controlled method of post-coital contraception. ${ }^{4,5}$ However, the most challenging aspect in reaching the full potential of this approach is that both healthcare personnel and potential users are both quite ignorant it. ${ }^{6}$ The beneficiaries, who know little about it, think that EC use is associated with frequent and severe side effects. ${ }^{7-9}$ Currently available 
commonly acknowledged hormonal method of post-coital contraception was first described by Yuzpe and Lancee and Yuzpe et al. Based on the findings of these authors, each dosage included the combination of $200 \mu \mathrm{g}$ ethinyl oestradiol and $2 \mathrm{mg}$ dl-norgestrel given in two divided doses where the second dose was given after $12 \mathrm{~h}$ of the first dose, within $72 \mathrm{~h}$ of unprotected intercourse. ${ }^{10,11,12}$

Several efficacious and easy to use methods for emergency contraception (EC) are available on the market today with the most widely spread being levonorgesterol (LNG) in a single dose of $1.5 \mathrm{mg}$ (given as one tablet of $1.5 \mathrm{mg}$ or 2 tablets of $0.75 \mathrm{mg}$ each) for administration up to 3 days after unprotected Sexual Intercourse. $^{13}$

The legal availability of ECs in India has not brought the use of ECs in the limelight and empirical data on their acceptability and use are still scarce. Data from the 20152016 Indian National Family Health Survey (NFHS-4) indicate that $47.7 \%$ and $50.7 \%$ of women and men, respectively, had ever heard of ECs. ${ }^{2}$

Out of the 700,000 women interviewed in the survey, the proportion of women who have ever used ECs was $0.4 \%$ and those who used EC in the last 12 months was $0.2 \% .^{2}$ The use of ECs is limited not just in developing countries, but their use remains suboptimal-even in the countries like United States and Australia. ${ }^{14,15}$

The NFHS-4 data further indicates that $60-75 \%$ of sexually active men and $42-85 \%$ sexually active women did not use any contraceptive method during their last sexual encounter. ${ }^{2}$

The same data suggests a wide gap between total fertility rate (2.2) and wanted fertility rate (1.8), indicating the limited control of females or couples over their family size.

It has also been estimated that the proportion of maternal mortality caused by unsafe abortions in India is $9 \%$, indicating that abortion services are not accessible to women. ${ }^{16}$ In the current scenario, ECs look to remain an underutilized tool to avoid unintended pregnancies and unsafe abortions in our country.

However, not much is known about the knowledge, attitude and practices (KAP) about ECs among reproductive age females, and thus this study was carried out to fill this KAP gap.

\section{METHODS}

This cross-sectional study was done among the adult females, aged 18 years and above, who visited the various out-patient departments (OPD) of a tertiary care hospital in July 2017. The hospital is a 500 bedded multispecialty hospital which is located on 29.4 acres of land situated at Rohini. It provides comprehensive medical care services to the residents of North and North West Delhi.

\section{Inclusion criteria}

- Women who attended the outpatient departments of medicine, surgery, orthopedics and gynecology, were more than 18 years of age and who were able to understand either Hindi or English were included in the study.

\section{Exclusion criteria}

- Women who were seriously ill, mentally unsound or not able to communicate and unwilling to participate in the study were excluded.

The study protocol was approved by the ethics committee of the institution. A convenience sample of 640 was randomly collected, with the help of chit method, from medicine, surgery, Orthopedics and Gynecology OPDs. Sampling was done every day and was completed in 4 weeks. The participants were informed of the objectives and procedures of the survey and assured that the information collected would be kept confidential. Those who gave written consent were included in the study.

The tool used was a pre-tested and semi-structured questionnaire whose content validation was done before hand. The questionnaire included socio-economic data of the respondent such as education, age, type of family, marital status, number of children. After that, knowledge, attitude and practices about ECs were assessed with the help of the study questionnaire. Awareness and usage pattern of other contraceptive methods were also assessed.

The study participants were counseled after the interview regarding the emergency contraception methods. The definition of emergency contraception used was: methods of contraception that can be used to prevent pregnancy in the first few days after intercourse, intended for emergency use following unprotected intercourse, contraceptive failure or misuse (such as forgotten pills or torn condoms), rape or coerced sex.

\section{Statistical analysis}

Data were entered and analyzed using SPSS ver 16. Chisquare test was used to test association. A p-value of less than 0.05 was considered as significant association.

\section{RESULTS}

Out of the 640 women who participated in the study, 614 $(95.9 \%)$ were Hindu and rest were Muslim. Most of the women were between the age of 20 to 29 years (317, $49.5 \%)$, were married $(578,90.3 \%)$ and had one or more children $(532,83.1 \%)$ (Table 1). Among the subjects, 333 $(52 \%)$ were aware of the term 'contraception' and only 
$113(17.7 \%)$ were aware of the term 'emergency contraception'.

Table 1: Socio-demographic details of study participants $(\mathrm{N}=640)$.

\begin{tabular}{|l|l|l|l|}
\hline \multirow{2}{*}{ Particulars } & Responses & Frequency & $\%$ \\
\hline \multirow{2}{*}{ Religion } & Joint & 417 & 65.2 \\
\hline \multirow{2}{*}{ Sex } & Nuclear & 223 & 34.8 \\
\hline \multirow{5}{*}{ Age (years) } & Hindu & 614 & 95.9 \\
\cline { 2 - 4 } & Muslim & 26 & 4.1 \\
\hline \multirow{3}{*}{ Marital status } & Females & 640 & 100 \\
\hline \multirow{3}{*}{ Number of children } & $<20$ & 87 & 13.6 \\
\hline & 20 to 29 & 317 & 49.5 \\
\hline & 30 to 39 & 144 & 22.5 \\
\hline & 40 or more & 92 & 14.4 \\
\hline & Married & 578 & 90.3 \\
\hline & Unmarried & 62 & 9.7 \\
\cline { 2 - 4 } & 0 & 108 & 16.9 \\
\hline & 2 & 156 & 24.4 \\
\hline
\end{tabular}

Among the women who were aware of emergency contraception $(113,17.7 \%)$, the only method of emergency contraception that they were aware of was ipill and the most common source of their information was friends, relatives or spouse $(49,43.4 \%)$.

When asked about the purpose of using ECs, 99 (87.6\%) said that it was to avoid unwanted pregnancy, $19(16.8 \%)$ said it was for spacing of births and rest $12(10.6 \%)$ were unaware of the purpose. When asked about the circumstances under which ECs are used, 70 (62\%) women answered as unprotected intercourse, 38 (33.6\%) said after a missed period, 25 (22.2\%) said after failure of barrier method, $14(12.4 \%)$ said after failure of coitus interrupts and rest $28(24.85 \%)$ did not know (Table 2). Three questions were asked to assess the attitude of participants towards the use of ECs. The first question was on willingness to use ECS, second was whether they think that use of ECs is beneficial in any way and third question was whether they will recommend the use of ECs to friends or relatives.

Table 2: Knowledge regarding ECs among participants.

\begin{tabular}{|c|c|c|c|c|}
\hline Questions & $\mathbf{N}$ & Responses & n & $\%$ \\
\hline \multirow{2}{*}{ Are you aware of the term 'contraception'? } & \multirow{2}{*}{640} & No & 307 & 48.0 \\
\hline & & Yes & 333 & 52.0 \\
\hline \multirow{2}{*}{ Are you aware of the term 'emergency contraception'? } & \multirow{2}{*}{640} & No & 527 & 82.3 \\
\hline & & Yes & 113 & 17.7 \\
\hline \multirow{2}{*}{ Which methods can be used as ECs? } & \multirow{2}{*}{113} & I- Pill (levonorgestrol) & 113 & 100.0 \\
\hline & & Others & 0 & 0.0 \\
\hline \multirow{3}{*}{ What was the source of your knowledge about ECs? } & \multirow{3}{*}{113} & Newspaper, magazine, banner, poster & 28 & 24.8 \\
\hline & & Friends, relatives, spouse & 49 & 43.4 \\
\hline & & $\begin{array}{l}\text { Health personnel: doctor, nurse, } \\
\text { paramedical worker }\end{array}$ & 36 & 31.8 \\
\hline \multirow{5}{*}{ What is the place of availability of ECs?* } & \multirow{5}{*}{113} & Government Hospital & 87 & 77.0 \\
\hline & & Health centers e.g. PHC, sub centers & 77 & 68.1 \\
\hline & & private health care institutes & 25 & 22.1 \\
\hline & & $\begin{array}{l}\text { Over the counter e.g. medical shop } \\
\text { pharmacy }\end{array}$ & 75 & 66.4 \\
\hline & & Others & 2 & 1.8 \\
\hline \multirow{2}{*}{ Is it necessary to use ECs under any circumstances? } & \multirow{2}{*}{113} & No & 7 & 6.2 \\
\hline & & Yes & 106 & 93.8 \\
\hline \multirow{3}{*}{ What is the purpose of using ECs?* } & \multirow{3}{*}{113} & To prevent unwanted pregnancy & 99 & 87.6 \\
\hline & & Spacing of Birth & 19 & 16.8 \\
\hline & & Don't Know & 12 & 10.6 \\
\hline \multirow{5}{*}{ Under what circumstances, the use of ECs is necessary?* } & \multirow{5}{*}{113} & After unprotected intercourse & 70 & 62.0 \\
\hline & & After missed period & 38 & 33.6 \\
\hline & & After failure of barrier method & 25 & 22.2 \\
\hline & & After failed coitus interrupts & 14 & 12.4 \\
\hline & & Don't know & 28 & 24.8 \\
\hline
\end{tabular}

*The responses are not mutually exclusive due to multiple responses. 
Almost half of the women $(52 \%)$ answered all the three questions positively (Table 3).

Out of 640 women who were interviewed, only 34 (5.3\%) had ever used an i-pill as an emergency contraceptive. Out of the 34 women who had used the i-pill, all were satisfied with the outcome though $8(23.5 \%)$ women experienced side effects like nausea, vomiting or some other effects.

When asked about whether they have ever used any other contraceptive method, only $264(41.2 \%)$ women out of 640 replied with a 'yes'. The most common method of contraception that was used was condoms (50.8\%), followed by tubectomy (22.3\%), Copper-T (21.6\%) and oral pills $(5.3 \%)$.
Table 3. Attitude of participants towards ECs $(\mathrm{N}=640)$.

\begin{tabular}{|l|l|l|l|}
\hline Questions & Responses & n & $\%$ \\
\hline \multirow{2}{*}{ Are you willing to use ECs? } & No & 307 & 48.0 \\
\cline { 2 - 4 } & Yes & 333 & 52.0 \\
\hline \multirow{2}{*}{ Is it beneficial to use ECs? } & No & 305 & 47.7 \\
\cline { 2 - 4 } & Yes & 335 & 52.3 \\
\hline $\begin{array}{l}\text { Would you encourage your } \\
\text { friends and relatives to use }\end{array}$ & No & 305 & 47.7 \\
\hline $\begin{array}{l}\text { ECs? } \\
\text { En }\end{array}$ & Yes & 335 & 52.3 \\
\hline
\end{tabular}

The most common reasons given for not using a contraceptive method were lack of knowledge (27.9\%), desire to have a child $(20.7 \%)$, no sexual contact $(18.6 \%)$, fear of side effects (11.2\%) and opposition of spouse or partner (95) (Table 4).

Table 4: Practices regarding contraceptives including ECs among participants.

\begin{tabular}{|c|c|c|c|c|}
\hline Questions & $\mathbf{N}$ & Responses & n & $\%$ \\
\hline \multirow{2}{*}{ Have you ever used ECs? } & \multirow{2}{*}{640} & No & 606 & 94.7 \\
\hline & & Yes & 34 & 5.3 \\
\hline \multirow{2}{*}{ If yes, then which type of EC did you use? } & \multirow{2}{*}{34} & I-Pill & 34 & 100.0 \\
\hline & & Others & 0 & 0.0 \\
\hline \multirow{2}{*}{$\begin{array}{l}\text { Were you satisfied with the outcome of use of } \\
\text { EC? }\end{array}$} & \multirow{2}{*}{34} & No & 0 & 0.0 \\
\hline & & Yes & 34 & 100.0 \\
\hline \multirow{2}{*}{ Did you have any side effects after you used EC? } & \multirow{2}{*}{34} & No & 26 & 76.5 \\
\hline & & Yes & 8 & 23.5 \\
\hline \multirow{2}{*}{ If yes, then what side-effects did you experience? } & \multirow{2}{*}{8} & Nausea, vomiting & 4 & 50.0 \\
\hline & & Others & 4 & 50.0 \\
\hline \multirow{2}{*}{ Have you ever used any other contraceptive method } & \multirow{2}{*}{640} & No & 376 & 58.8 \\
\hline & & Yes & 264 & 41.2 \\
\hline \multirow{5}{*}{$\begin{array}{l}\text { If yes, then what contraceptive methods have you } \\
\text { ever used? }\end{array}$} & \multirow{5}{*}{264} & Oral Pills & 14 & 5.3 \\
\hline & & Condoms & 134 & 50.8 \\
\hline & & Copper T & 57 & 21.6 \\
\hline & & Tubectomy & 59 & 22.3 \\
\hline & & Conventional methods & 2 & 0.8 \\
\hline \multirow{10}{*}{$\begin{array}{l}\text { If no, then what was the reason of never using a } \\
\text { contraceptive? }\end{array}$} & \multirow{10}{*}{376} & Currently pregnant & 2 & 0.5 \\
\hline & & Desire to have child & 78 & 20.7 \\
\hline & & Fear of side effects & 42 & 11.2 \\
\hline & & Husband undergone vasectomy & 2 & 0.5 \\
\hline & & Lack of knowledge & 105 & 27.9 \\
\hline & & Never had any sexual contact & 70 & 18.6 \\
\hline & & $\begin{array}{l}\text { No response/ Not willing to disclose } \\
\text { the reason }\end{array}$ & 14 & 3.7 \\
\hline & & Opposition of family members & 16 & 4.3 \\
\hline & & Opposition of spouse/ partner & 34 & 9.0 \\
\hline & & Post-partum period or breast feeding & 15 & 4.0 \\
\hline
\end{tabular}

The awareness of contraception and emergency contraception was significantly associated with increased age ( $\mathrm{p}$ value $=0.026$ and 0.0001 respectively). The positive attitude regarding usage of ECs, consisting of willingness to use ECs, finding it beneficial encouraging others to use ECs, was significantly associated with increased age, being married and having one or more children $(\mathrm{p}$ value $=0.0001)$. The practice of using ECs was significantly more in the age group of 30-39 years. 
Table 5: Factors associated with awareness, attitude and practices regarding emergency contraceptives.

\begin{tabular}{|c|c|c|c|c|c|c|c|c|c|c|c|}
\hline \multirow{2}{*}{\multicolumn{3}{|c|}{ Variables }} & \multicolumn{3}{|l|}{ Age } & \multicolumn{2}{|c|}{ Marital status } & \multicolumn{4}{|c|}{ No. of Children } \\
\hline & & & $<30$ & 30-39 & $\geq 40$ & Married & Unmarried & 0 & $1-2$ & \multirow{2}{*}{$\begin{array}{l}>\mathbf{2} \\
72 \\
(45.0)\end{array}$} & \multirow{2}{*}{$\begin{array}{l}\text { Total } \\
307 \\
(48)\end{array}$} \\
\hline \multirow{8}{*}{ 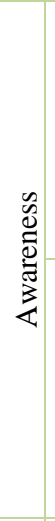 } & \multirow{4}{*}{$\begin{array}{l}\text { Aware of } \\
\text { term } \\
\text { contraception }\end{array}$} & No & $210(52)$ & $\begin{array}{l}61 \\
(42.4)\end{array}$ & $36(39.1)$ & $\begin{array}{l}270 \\
(46.7)\end{array}$ & 37 (59.7) & $56(51.9)$ & $\begin{array}{l}179 \\
(48.1)\end{array}$ & & \\
\hline & & Yes & $194(48)$ & $\begin{array}{l}83 \\
(57.6)\end{array}$ & $56(60.9)$ & $\begin{array}{l}308 \\
(53.3)\end{array}$ & $25(40.3)$ & $52(48.1)$ & $\begin{array}{l}193 \\
(51.9)\end{array}$ & $\begin{array}{l}88 \\
(55.0)\end{array}$ & $\begin{array}{l}333 \\
(52)\end{array}$ \\
\hline & & Total & $\begin{array}{l}404 \\
(100)\end{array}$ & $\begin{array}{l}144 \\
(100)\end{array}$ & $92(100.0)$ & $\begin{array}{l}578 \\
(100)\end{array}$ & $62(100)$ & $108(100)$ & $\begin{array}{l}372 \\
(100)\end{array}$ & $\begin{array}{l}160 \\
(100)\end{array}$ & $\begin{array}{l}640 \\
(100)\end{array}$ \\
\hline & & P Value & \multicolumn{3}{|l|}{0.026} & \multicolumn{2}{|l|}{0.052} & \multicolumn{4}{|l|}{0.543} \\
\hline & \multirow{4}{*}{$\begin{array}{l}\text { Aware of } \\
\text { term } \\
\text { emergency } \\
\text { contraception }\end{array}$} & No & $\begin{array}{l}338 \\
(83.7)\end{array}$ & $\begin{array}{l}103 \\
(71.5)\end{array}$ & $86(93.5)$ & $\begin{array}{l}473 \\
(81.8)\end{array}$ & $54(87.1)$ & $89(82.4)$ & $\begin{array}{l}302 \\
(81.2)\end{array}$ & $\begin{array}{l}136 \\
(85.0)\end{array}$ & $\begin{array}{l}527 \\
(82.3)\end{array}$ \\
\hline & & Yes & $\begin{array}{l}66 \\
(16.3)\end{array}$ & $\begin{array}{l}41 \\
(28.5)\end{array}$ & $6(6.5)$ & $\begin{array}{l}105 \\
(18.2)\end{array}$ & $8(12.9)$ & 19 (17.6) & $\begin{array}{l}70 \\
(18.8)\end{array}$ & $\begin{array}{l}24 \\
(15.0)\end{array}$ & $\begin{array}{l}113 \\
(17.7)\end{array}$ \\
\hline & & Total & $\begin{array}{l}404 \\
(100)\end{array}$ & $\begin{array}{l}144 \\
(100)\end{array}$ & $92(100)$ & $\begin{array}{l}578 \\
(100)\end{array}$ & $62(100)$ & 108 (100) & $\begin{array}{l}372 \\
(100)\end{array}$ & $\begin{array}{l}160 \\
(100)\end{array}$ & $\begin{array}{l}640 \\
(100)\end{array}$ \\
\hline & & P Value & \multicolumn{3}{|l|}{0.0001} & \multicolumn{2}{|l|}{0.302} & \multicolumn{4}{|l|}{0.571} \\
\hline \multirow{12}{*}{ 莺 } & & No & $\begin{array}{l}213 \\
(52.7)\end{array}$ & $\begin{array}{l}42 \\
(29.2)\end{array}$ & $52(56.5)$ & $\begin{array}{l}247 \\
(42.7)\end{array}$ & $60(96.8)$ & $\begin{array}{l}79 \\
(73.1)\end{array}$ & $\begin{array}{l}150 \\
(40.3)\end{array}$ & $\begin{array}{l}78 \\
(48.8)\end{array}$ & $\begin{array}{l}307 \\
(48.0)\end{array}$ \\
\hline & Willing to & Yes & $\begin{array}{l}191 \\
(47.3)\end{array}$ & $\begin{array}{l}102 \\
(70.8)\end{array}$ & $40(43.5)$ & $\begin{array}{l}331 \\
(57.3)\end{array}$ & $2(3.2)$ & $\begin{array}{l}29 \\
(26.9)\end{array}$ & $\begin{array}{l}222 \\
(59.7)\end{array}$ & $\begin{array}{l}82 \\
(51.2)\end{array}$ & $\begin{array}{l}333 \\
(52.0)\end{array}$ \\
\hline & & Total & $\begin{array}{l}404 \\
(100)\end{array}$ & $\begin{array}{l}144 \\
(100)\end{array}$ & $92(100.0)$ & $\begin{array}{l}578 \\
(100)\end{array}$ & $62(100.0)$ & $\begin{array}{l}108 \\
(100)\end{array}$ & $\begin{array}{l}372 \\
(100)\end{array}$ & $\begin{array}{l}160 \\
(100)\end{array}$ & $\begin{array}{l}640 \\
(100)\end{array}$ \\
\hline & & P Value & 0.0001 & & & $0.0001 *$ & & 0.0001 & & & \\
\hline & & No & $\begin{array}{l}211 \\
(52.2)\end{array}$ & $42(29.2)$ & $52(56.5)$ & $245(42.4)$ & $\begin{array}{l}60 \\
(96.8)\end{array}$ & $\begin{array}{l}79 \\
(73.1)\end{array}$ & $\begin{array}{l}148 \\
(39.8)\end{array}$ & $\begin{array}{l}78 \\
(48.8)\end{array}$ & $\begin{array}{l}305 \\
(47.7)\end{array}$ \\
\hline & $\begin{array}{l}\text { Is it } \\
\text { beneficial to }\end{array}$ & Yes & $\begin{array}{l}193 \\
(47.8)\end{array}$ & $\begin{array}{l}102 \\
(70.8)\end{array}$ & $40(43.5)$ & $333(57.6)$ & $2(3.2)$ & $\begin{array}{l}29 \\
(26.9)\end{array}$ & $\begin{array}{l}224 \\
(60.2)\end{array}$ & $\begin{array}{l}82 \\
(51.2)\end{array}$ & $\begin{array}{l}335 \\
(52.3)\end{array}$ \\
\hline & use EC & Total & $\begin{array}{l}404 \\
(100)\end{array}$ & 144 (100) & $92(100)$ & $578(100)$ & $\begin{array}{l}62 \\
(100)\end{array}$ & $\begin{array}{l}108 \\
(100)\end{array}$ & $\begin{array}{l}372 \\
(100)\end{array}$ & $\begin{array}{l}160 \\
(100)\end{array}$ & $\begin{array}{l}640 \\
(100)\end{array}$ \\
\hline & & P Value & 0.0001 & & & 0.0 & & 0.0001 & & & \\
\hline & Would you & No & $\begin{array}{l}211 \\
(52.2)\end{array}$ & $42(29.2)$ & $52(56.5)$ & $245(42.4)$ & $\begin{array}{l}60 \\
(96.8)\end{array}$ & $\begin{array}{l}79 \\
(73.1)\end{array}$ & $\begin{array}{l}148 \\
(39.8)\end{array}$ & $\begin{array}{l}78 \\
(48.8)\end{array}$ & $\begin{array}{l}305 \\
(47.7)\end{array}$ \\
\hline & $\begin{array}{l}\text { encourage } \\
\text { your friends }\end{array}$ & Yes & $\begin{array}{l}193 \\
(47.8)\end{array}$ & $\begin{array}{l}102 \\
(70.8)\end{array}$ & $40(43.5)$ & $333(57.6)$ & $2(3.2)$ & $\begin{array}{l}29 \\
(26.9)\end{array}$ & $\begin{array}{l}224 \\
(60.2)\end{array}$ & $\begin{array}{l}82 \\
(51.2)\end{array}$ & $\begin{array}{l}335 \\
(52.3)\end{array}$ \\
\hline & $\begin{array}{l}\text { and relatives } \\
\text { to use EC }\end{array}$ & Total & $\begin{array}{l}404 \\
(100 .)\end{array}$ & 144 (100) & $\begin{array}{l}92 \\
(100.0)\end{array}$ & $578(100)$ & $\begin{array}{l}62 \\
(100)\end{array}$ & $\begin{array}{l}108 \\
(100)\end{array}$ & $\begin{array}{l}372 \\
(100)\end{array}$ & $\begin{array}{l}160 \\
(100)\end{array}$ & $\begin{array}{l}640 \\
(100)\end{array}$ \\
\hline & & P Value & 0.0001 & & & $0.0001 *$ & & 0.0001 & & & \\
\hline & & No & $\begin{array}{l}388 \\
(96.0)\end{array}$ & $128(88.9)$ & $\begin{array}{l}90 \\
(97.8)\end{array}$ & $544(94.1)$ & $62(100)$ & $\begin{array}{l}105 \\
(97.2)\end{array}$ & $\begin{array}{l}348 \\
(93.5)\end{array}$ & $\begin{array}{l}153 \\
(95.6)\end{array}$ & $\begin{array}{l}606 \\
(94.7)\end{array}$ \\
\hline & $\begin{array}{l}\text { Have you } \\
\text { ever used }\end{array}$ & Yes & $16(4.0)$ & $16(11.1)$ & $2(2.2)$ & $34(5.9)$ & 0 & $3(2.8)$ & $\begin{array}{l}24 \\
(6.5)\end{array}$ & $7(4.4)$ & $34(5.3)$ \\
\hline & & Total & $\begin{array}{l}404 \\
(100.0)\end{array}$ & $144(100)$ & $92(100)$ & $578(100)$ & $62(100)$ & $\begin{array}{l}108 \\
(100)\end{array}$ & $\begin{array}{l}372 \\
(100)\end{array}$ & $\begin{array}{l}160 \\
(100)\end{array}$ & $\begin{array}{l}640 \\
(100)\end{array}$ \\
\hline$\stackrel{\mathscr{U}}{.}$ & & P Value & 0.002 & & & $0.06 *$ & & $0.40 * *$ & & & \\
\hline$\overline{\tilde{Z}}$ & Have you & No & $\begin{array}{l}273 \\
(67.6)\end{array}$ & $69(47.9)$ & $\begin{array}{l}3 \\
4(37.0)\end{array}$ & $314(54.3)$ & $62(100)$ & $\begin{array}{l}85 \\
(78.7)\end{array}$ & $\begin{array}{l}222 \\
(59.7)\end{array}$ & $\begin{array}{l}69 \\
(43.1)\end{array}$ & $\begin{array}{l}376 \\
(58.8)\end{array}$ \\
\hline & $\begin{array}{l}\text { ever used } \\
\text { any other }\end{array}$ & Yes & $\begin{array}{l}131 \\
(32.4)\end{array}$ & $75(52.1)$ & $\begin{array}{l}58 \\
(63.0)\end{array}$ & $264(45.7)$ & 0 & $\begin{array}{l}23 \\
(21.3)\end{array}$ & $\begin{array}{l}150 \\
(40.3)\end{array}$ & $\begin{array}{l}91 \\
(56.9)\end{array}$ & $\begin{array}{l}264 \\
(41.2)\end{array}$ \\
\hline & $\begin{array}{l}\text { contraceptive } \\
\text { method }\end{array}$ & Total & $\begin{array}{l}404 \\
(100)\end{array}$ & 144 (100) & $92(100)$ & $578(100)$ & $62(100)$ & $\begin{array}{l}108 \\
(100)\end{array}$ & $\begin{array}{l}372 \\
(100)\end{array}$ & $\begin{array}{l}160 \\
(100)\end{array}$ & $\begin{array}{l}640 \\
(100)\end{array}$ \\
\hline & & P Value & 0.0001 & & & $0.0001 *$ & & 0.0001 & & & \\
\hline
\end{tabular}

\section{DISCUSSION}

World Health Organization (WHO) has defined family planning as "A way of thinking and living that is adopted voluntarily, upon the basis of knowledge, attitude and responsible decisions by individuals and couples, in order to promote the health and welfare of family groups and thus contribute effectively to the social development of the country". ${ }^{17}$

Any method of contraception will become acceptable to the public when it will fall within their social norms and when proper knowledge about it will be imparted to the public regarding its use and side effects. This study was conducted to find out the knowledge, attitude of 
reproductive age women regarding emergency contraception.

Though the use of ECs has long been legalized and it is available in the basket of choices offered to women for contraception, its awareness is not satisfactory, and the attitude of general public is far from positive. Only 52\% females were aware of the term 'contraception' and $17.7 \%$ were aware about emergency contraception. Other studies among Indian women have also reported low awareness about ECs. ${ }^{17,18}$ The awareness about ECs was reported to be higher (48-85.7\%) among other studies. ${ }^{19,20}$ The reasons could be the higher literacy rates among participants in other studies (participants were college students and nurses). Commonest sources of knowledge of almost half of the participants were informal sources like were friends, relatives and spouse, who may be unreliable and incorrect. ${ }^{19}$ Other studies have also reported them as most common source of information on ECs. ${ }^{20,21}$

Even if few people knew about ECs, the knowledge they had about them was limited. Only 70 women out of 640 knew that ECs can be taken after unprotected intercourse and a much lesser number of women (25 out of 640) knew that ECs can be taken after failure of a barrier contraceptive.

Thirty-eight women said that ECs can be taken after a missed period, which is clearly wrong information that is doing the rounds among masses. Other studies have also reported poor knowledge about ECs among participants. $^{18,19,22}$

The ignorance about ECs has not spared even the health care providers and they have reported poor knowledge and over-estimation of side-effects. ${ }^{22-24}$ It is estimated that correct information and use of ECs could prevent almost two-thirds of induced abortions. ${ }^{25}$ The awareness about ECs is significantly associated with age as is reported by another study. ${ }^{26}$

Less than half of the participants showed a positive attitude towards ECs. They were willing to use them; they thought it to be beneficial and were willing to recommend them to friends and relatives. A study done by Joseph et al among college students also reported that half of the participants were willing to recommend ECs to family and friends. ${ }^{19}$

A review of literature reported that majority of women in low-income countries have never heard of emergency contraception, and many providers have negative attitudes toward providing emergency contraception. ${ }^{27}$ The right attitude will come with right information. People should be made aware that ECs are a safe method to avoid pregnancies after unprotected intercourse and failure of barrier method. They should be told that ECs are not abortifacients, and neither should they be used as a substitute to other contraceptive methods.
When asked about use of contraceptives, not even half of the women (41.2\%) reported using any of the contraceptives ever. The most common methods of contraception they used were condoms (50.8\%), tubectomy $(22.3 \%)$ and copper-T $(21.6 \%)$. Another study done among low-income women in India also reported $52 \%$ usage of contraceptives. ${ }^{28}$

A study done by Takker et al among married women working in a hospital, however, reported a much higher percentage of contraceptive use $(81.1 \%)$, the reason of which may be higher literacy rate and more accessibility of the women to the contraceptives in the hospital. ${ }^{17}$ Almost one-third (27.9\%) women in the current study, stated lack of knowledge as the reason for not using a contraceptive. Desire to have a child, fear of side effects and opposition of spouse or partner were also important reasons stated for not using contraceptives. Clearly, the information, education and communication is lacking as far as the contraception especially emergency contraception is concerned. If authors are to achieve the desired fertility rate and reduce maternal mortality, then this topic is unavoidable and empirical.

Healthcare providers have a responsibility to bring about attitudinal changes so that hindrances in learning about ECPs can be removed in minds of the general public. This will also empower users in making informed decisions to regulate their fertility. ECs also give people a second chance at contraception and help in reducing unintended pregnancies and induced abortions.

Thus, they have a big role to play in a country like India where health of the women of reproductive age group is often neglected. Physicians should counsel patients on the use and effectiveness of emergency contraception, the methods available, and the benefits of routine and consistent contraception use.

The information related to reproduction and contraception should be disseminated through media and reach the masses. Health education sessions including sex education should be intensified so that false information and taboo doesn't put adolescents at risk of pregnancies and STIs. Awareness of community workers like ASHA and Anganwadi workers would also goa long way in changing the attitude of community towards contraception especially emergency contraception.

The study had various limitations. The profile of those who refused to participate might be different than those who did, but authors couldn't take into account the nonparticipation bias. The women who came to the hospital were mostly from the low socio-economic class so the results cannot be extrapolated to the rest of the population. Also, accuracy of responses provided by participants on a sensitive issue like emergency contraception cannot be guaranteed. However, the study gives us insights into the knowledge and attitude of a 
population that is the most suitable target for family planning methods especially emergency contraception.

\section{Funding: No funding sources}

Conflict of interest: None declared

Ethical approval: The study was approved by the Institutional Ethics Committee

\section{REFERENCES}

1. Singh A, Singh A, Mahapatra B. The consequences of unintended pregnancy for maternal and child health in rural India: evidence from prospective data. Matern Child Health J. 2013;17(3):493-500.

2. International Institute for Population Sciences (IIPS) and ICF. 2017. National Family Health Survey (NFHS-4), 2015-16: India [Internet]. Mumbai: IIPS. Available from: http://rchiips.org/NFHS/NFHS4Reports/India.pdf

3. Ramesh BM, Gulati SC, Retherford RD. Contraceptive use in India 1992-1993, national family health survey subject reports, number 2 [Internet]. Mumbai: International Institute for Population Sciences; 1996. Available from: https://www.eastwestcenter.org/node/33437

4. Family Planning Division, Ministry of Health and Family Welfare. Guidelines for Administration of Emergency Contraceptive Pills by Health Care Providers. New Delhi: MoHFW; Nov 2008. Available from: http:// mohfw.nic.in/NRHM/FP/ECP_Book_Final.pdf

5. Trussell J, Raymond EG. Emergency Contraception: A Last Chance to Prevent Unintended Pregnancy [Internet]. Princeton, New Jersey: Princeton University, Office of Population Research; 2017. 38. Available

from: https://www.popline.org/node/664747

6. The Lancet Editorial. After the morning after and the morning after that. Lancet. 1995;345(8962):1381-2.

7. Cayley J. Emergency contraception. BMJ. 1995;311(7008):762-3.

8. Pearson VA, Owen MR, Phillips DR, Gray DP, Marshall MN. Pregnant teenagers' knowledge and use of emergency contraception. BMJ. 1995;310(6995):1644..

9. Pillaye J, Rahwan R. Morning-after birth control. The Lancet. 1995;346(8969):251-2.

10. Yuzpe AA, Lancee WJ. Ethinyl oestradiol and dlnorgestrel as a postcoital contraceptive. Fertil Steril. 1977;28(9):932-6.

11. Yuzpe AA, Smith RP, Rademaker AW. A multicenter clinical investigation employing ethinyl oestradiol combined with dl-norgestrel as a postcoital contraceptive agent. Fertil Steril. 1982;37(4):508-13.

12. Shohel M, Rahman MM, Zaman A, Uddin MM, AlAmin MM, Reza HM. A systematic review of effectiveness and safety of different regimens of levonorgestrel oral tablets for emergency contraception. BMC Womens Health. 2014 Apr 4;14(1):54.
13. Gemzell-Danielsson K, Rabe T, Cheng L. Emergency contraception. Gynecol Endocrinol. 2013;29(1):1-14.

14. Devine KS. The underutilization of emergency contraception. Am J Nurs. 2012;112(4):44-50.

15. Mazza D, Harrison CM, Taft AJ, Britt HC, Hobbs M, Stewart K, Hussainy S, Brijnath BR. Emergency contraception in Australia: the desired source of information versus the actual source of information. Med J Aust. 2014;200(7):414-5.

16. Sample Registration System. Maternal mortality in India: 1997-2003 - trends, causes and risk factors [Internet]. New Delhi: SRS; 2006. Available from: http://www.cghr.org/wordpress/wpcontent/uploads/RGI-CGHR-Maternal-Mortality-inIndia-1997\%E2\%80\%932003.pdf

17. Takkar N, Goel P, Saha PK, Dua D. Contraceptive practices and awareness of emergency contraception in educated working women. Indian J Med Sci. 2005 Apr;59(4):143-9.

18. Kathpalia SK. Emergency contraception: Knowledge and practice among women and the spouses seeking termination of pregnancy. Med J Armed Forces India. 2016;72(2):116-9

19. Joseph N, Shetty B, Hasreen F, Ishwarya R, Baniya M, Sachdeva S, Agarwal S. Awareness and Attitudes Toward Emergency Contraceptives Among College Students in South India. J Obstet Gynaecol India. 2016;66(1):363-9.

20. Kongnyuy EJ, Ngassa P, Fomulu N, Wiysonge CS, Kouam L, Doh AS. A survey of knowledge, attitudes and practice of emergency contraception among university students in Cameroon. BMC Emerg Med. 2007;7(1):7.

21. Ojule JD, Oriji VK, Georgewill KN. Awareness and practice of emergency contraception among students of University of Port Harcourt, South-South Nigeria. Niger Health J. 2008;8(1-2):6-9.

22. Langer A, Harper C, Garcia-Barrios C, Schiavon R, Heimburger A, Elul B, Renoso Delgado S, Ellertson C. Emergency contraception in Mexico City: what do healthcare providers and potential users know and think about it? Contracep. 1999;60(4):233-41.

23. Tripathi R, Rathore A.M., Sachdev J. Emergency contraception: knowledge, attitude and practice among health care providers in North India. J Obstet Gynaecol India. 2003;29(3):142-6.

24. Rahaman H, Renjhen P, Kumar A. A study on emergency contraceptive practice among nursing staff in Sikkim, India - a cross sectional study. Aust Med J. 2010;3(10):667-71.

25. Nalini A, Mittal S. Emergency contraception and prevention of induced abortions in India. J Fam Plann Reprod Health Care. 2005;31(4):294-6.

26. Kozinszky Z, Sikovanyecz J, Devosa I, Szabó D, Barabás K, Pál A, Arthur J. Determinants of emergency contraceptive use after unprotected intercourse: who seeks emergency contraception and who seeks abortion? Acta Obstet Gynecol Scand. 2012;91(8):959-64. 
27. Westley E, Kapp N, Palermo T, Bleck J. A review of global access to emergency contraception. Int $\mathrm{J}$ Gynaecol Obstet. 2013;123(1):4-6.

28. Kumar M, Meena J, Sharma S, Poddar A, Dhalliwal V, Modi-Satish Chander Modi SC, Singh K. Contraceptive use among low-income urban married women in India. J Sex Med. 2011;8(2):376-82.
Cite this article as: Renjhen $\mathrm{P}$, Kumar V, Rathi A, Loukya A. Contraceptive practices and awareness about emergency contraception among women attending a tertiary care hospital of Delhi, India. Int J Reprod Contracept Obstet Gynecol 2019;8:1047-54. 